\title{
Technological Monitoring Applied to Survey-Based on Brazilian Patent Applications about PEMFC
}

\author{
Deysimar de Souza Carvalho',2, Eduardo Winter', Cheila Gonçalves Mothé2, Tatiana Carestiato'
}

\begin{abstract}
The present study aims to show the importance of patents as an instrument of technological innovation and to assess the relevance of technology of PEMFC in Brazil by means of the technological monitoring methodology from 1996 to 2005. This study used different Industrial Property Databases (INPI-BR, ESPACENET and DWPI), in order to retrieve the BR applications in each database. Relevant keywords as "fuel cell" were used in combination with specific IPC (H0IM8) in order to assess the main applicants, countries, IPCs and technological innovation over time. In Brazil, the country holding more requests in this area is the United States (US) with 53,7\% of the patent applications, while Brazil (BR) accounts for $4,4 \%$ of the total requests. It was also observed that the North-American company, UTC Fuel Cells comes on top of the list and that there were no patent applications of Brazilian origin (BR) in other countries.
\end{abstract}

Keywords: PEM; PEMFC; fuel cells; ion exchange membrane; proton exchange membrane.

\footnotetext{
' Brazilian Institute of Industrial Property (INPI-Br), Rua Mayrink Veiga, 9 - Centro, 190 Andar, CEP: 20.090-910, Rio de Janeiro, RJ, Brazil, Phone: +55 (21) 21393767 / 21393379 / 2139-3868, E-mail: deysimar@inpi.gov.br; tatianac@inpi.gov.br; winter@inpi.gov.br

2 Department of Organic Process, School of Chemistry, sala E-204, Federal University of Rio de Janeiro, Ilha do Fundão, CEP 2194I-909, Rio de Janeiro, RJ, Brazil, Phone: +55 (2I) 2562-7587, E-mail: cheila@eq.ufri.br
} 


\section{Introduction}

The industrial revolution and the urban explosion that happened in the 19th century led to devastating impacts on nature, especially the ones related to air pollution. The fossil fuels are pollutants that bring several problems to mankind and the environment, due to toxic gases released in the atmosphere, like carbon monoxide (CO), carbon dioxide (CO2), sulfur and nitrogen oxides (SOx e NOx), hydrocarbons among other particulate matters (Costa, 2007). Thus, due to the preoccupation in preserving the environment and the need for alternatives that are capable of lessening the global warming, new clean and renewable sources of energy have been developed. In addition, the global climate changes have raised the interest and preoccupation of governments, international organizations and the society. Collaterally to this, industries have also tried to reach both, economical and environmental sustainability.

In Brazil, the bureau in charge of the conception and implementation of policies regarding the energy sector is the Ministry of Mines and Energy (MME). in accordance with the guidelines of the National Council for Energy Policy (CNPE), which was established on Aug-6-1997 by law n. 9.478. In 2002, the Ministry of Science and Technology (MCT), together with the participation of universities, research centers and Brazilian companies established the Brazilian Program of Hydrogen and Fuel Cells System (PROCAC) in order to promote integrated and cooperated actions that enable the national development of the hydrogen technology and the fuel cells system. From 2005 on, this program was called "Science, Technology and Innovation to Hydrogen Economy Program" $(\mathrm{PROH} 2)$. This program aims to establish the national industry, the production and supply of energy systems of fuel cells, and to make the country an internationally competitive producer in this area (Bragion, 2007).

Due to this scenario, fuel cells come as a promising technology to replace fossil fuels. There is great enthusiasm and momentum among legislators, researchers and fuel cell developers to accelerate the entry of fuel cell power sources into the commercial sector.

Although the Brazilian energy matrix is largely based on hydraulic resources and on the use of sugar cane energy, among other renewable resources, this technology (fuel cell power) is also relevant to Brazil. Since the global issue of greenhouse gases emissions is also a concern in Brazil, this country needs to invest in alternative energy, especially in terms of vehicular fuel. Thus, fuel cells powered by hydrogen and oxygen from the air have proven to be an environmentally accepted and energy efficient alternative.

A fuel cell can be defined as an electro-chemical device that continually transforms the chemical energy in electric energy without rotary motion or combustion, since it has a source of oxide and fuel. The fuel is the hydrogen or a composite containing it, and the oxidant is the oxygen. The use of hydrogen (as fuel) and air (as oxidant) in the fuel cells presents as advantages the fact that the sub-products of the reaction are heat and water, which can be viewed as "zero emissions" (Cheng et al., 2007). However, even when used with fossil fuels, the levels of air pollution are considerably lower, because of the elevated yield of this kind of technology, which allows reductions in the consumption of these fuels.

There are many kinds of fuel cells, but the basic principles are the same. The main kinds of fuel cells are classified according to the functioning temperature (Costa, 2007). Nowadays, there are basically five main kinds of fuel cells: PEMFC - Proton Exchange Membrane Fuel Cell; AFC Alkali Fuel Cell; PAFC - Phosphoric Acid Fuel Cell; SOFC Solid oxide fuel cell; MCFC - Molten Carbonate Fuel Cell.

Up to the mid 1990s, the bulk of R\&D efforts was to develop power plants for power generation/co-generation applications. It was predicted that the PAFC, MCFC, and SOFC would be the first, second, and third generation power plants, respectively. Since the early 1990s, there was a great impetus for developing fuel cells for transportation applications because of the US Partnership for a New Generation of Vehicles Program involving the collaboration of the US Federal Government with the three major automobile companies: General Motors, Ford, and Chrysler. Moreover, Daimler/Chrysler, followed by Toyota, Honda, Ford/Mazda, and Volkswagon, made most progress. All these developments were with PEMFC power plants (Srinivasan, 2006; Sopian and Daud, 2006; Basu, 2007). 
For both power generation/co-generation and transportation applications, the capital costs and lifetime have been the overriding factors in retarding the entry of fuel cells into the commercial sector. The PEMFC is a rugged, quite clean, and energy efficient conversion means for transportation application (Srinivasan, 2006; Sopian and Daud, 2006).

A sign of dominance of PEMFC in recent times is reflected in the number of companies that have sprouted "manufacturing" these units, various demonstration programs, and increase in the number patents. A growing number of global corporations are becoming involved in fuel cells, both as developers and strategic partners. Large established manufacturers, such as DuPont, Gore, SGL, 3M and Johnson Matthey, are positioning themselves to become world suppliers of PEMFC components (Basu, 2007).

Thus, among the known fuel cells, the PEMFC is the one that stands out the most, mainly because they work at low temperatures and are suitable for adaptation and generation of electric energy, in either a stationary, portable or vehicular way, once that, from the technological point of view, it has shown to be the most promising, simultaneously associating performance and economy. Such technical characteristics put the fuel cells that use membranes on top of the list of fuel cells commercialized in the world.

The technical characteristics of PEMFC are: the electrolyte is a polymeric membrane that allows the exchange of protons of hydrogen. Their yield is around 40 to $50 \%$. They work at temperatures around 60 to $80{ }^{\circ} \mathrm{C}$ and have been developed in potencies ranging from I W to 250 KW (Hartmut, Götz and Linardi, 2000).

The main component of the operating PEMFC is the polymer membrane that has the ability to be impervious to gases, but which allows the passage of protons in its structure. This membrane is surrounded on both sides by a porous layer of electrolyte, typically composed of carbon fiber paper, in which, at the insertion of hydrogen and oxygen gases this compound is compressed. At the junction of the electrolyte and the membrane a platinum catalyst is used in order to accelerate the chemical reaction when breaking the molecules of the gases (hydrogen and oxygen) (Franchi, 2009).

Moreover, one key element to determine the performance of the PEMFC is the water-content dependence of the protonic conductivity in the polymeric membrane employed in it. The high protonic conductivity provided by the membrane under humidification conditions and at current densities typically required in PEMFCs is the most important property of this membrane (Biyikoğlu, 2005).

In addition, the perfluorinated polymer electrolyte membranes such as Nafion (DuPont), Aciplex (Ashahi Chemicals Co.), Flemin (Ashahi Glass Co.) and Dow (Dow Chemical Co.) have been extensively used as polymer electrolytes for fuel cells because of their stable electrochemical and mechanical properties.

According to Srinivasan (2006), the most critical challenges in PEMFC are as follow: (i) Find alternate/modified proton conducting membranes, lower their cost and operate at temperatures up to 120 to $130{ }^{\circ} \mathrm{C}$; (ii) Further lower $\mathrm{Pt}$ loading on both electrodes; (iii) Lower costs of production of bipolar plates and possibly replace carbon with metallic plates; (iv) Operate PEMFCs with no or under humidification of reactant gases; (v) Investigate causes for performance degradation and find methods to reduce this behavior; (vi) Lower fabrication costs of cell stacks.

Sopian and Daud (2006) shows that reduction of membrane cost could be achieved by using non-fluorinated polymer electrolytes with a cheaper sulfonated polymer backbone. Sulfonation of poly(ether ketone), poly(styrene) and related materials produces high proton conductivity polymers free of fluorine. Grafting of short sulfonate terminated side groups would increase thermal stability. Extensive research has been done to produce cheaper membranes to replace DuPont's Nafion use of commercially available polymer membranes.

Moreover, current polymer electrolyte membranes must be fully hydrated for good proton conduction. The PEMFC system therefore requires the provision of a water management system that consists of air and fuel gas humidifiers and water recovery system. PEMFC system complexity could be reduced by the development of "water-free" electrolytes that do not require hydration. It also enables PEMFC to be operated under "warm" conditions (i.e. above $100{ }^{\circ} \mathrm{C}$ ) thus further improving its efficiency. Capital cost could also be further reduced because at warmer conditions less Pt could be used. Acid-base polymer complexes where a strong acid is coupled to a highly basic polymer are good proton conductors without hydration. Basic polymers in combination with sulfuric, phosphoric and various halide acids could also be used (Sopian and Daud, 2006). 
Another problem occurs when PEMFC uses fossil fuels in hydrogen fuel manufacturing processes, called reformation. This fuel has impurities, such as $\mathrm{CO}, \mathrm{H} 2 \mathrm{~S}, \mathrm{NH} 3$, organic sulfur-carbon and carbon-hydrogen compounds. The air also has impurities, such as NOx, SOx, and small organics, wich are brought along with the fuel and feed streams into the anodes and cathodes of a PEMFC, causing performance degradation, and sometimes permanent damage to the membrane electrode assemblies (MEA). This effect of contaminants on fuel cells is one of the most important issues in fuel cell operation (Cheng et al., 2007).

The reformed $\mathrm{H} 2$-rich gas is the dominant source of fuel. This fuel contains appreciable amounts of $\mathrm{CO}$ and $\mathrm{CO}$, which are the major fuel cell anode contaminants. Thus, there are several effective methods available to mitigate $\mathrm{CO}$ poisoning in PEMFC, such as enhancing $\mathrm{CO}$ oxidation by pre-treating reformate, introducing an anode oxidantbleed, developing $\mathrm{CO}$-tolerant catalysts, and optimizing fuel cell operating conditions (Cheng et al., 2007).

It is important to note that for a long-term supply of hydrogen, reformate may not be an option due to the fossil hydrogencarbon shortage. It is expected that the external supply of hydrogen will rely on electrolysis and reformate from renewable biomass materials such as methanol and ethanol. For $\mathrm{H} 2$ production from water electrolysis, $\mathrm{CO}$ fuel contamination may not be a problem. However, for short-term hydrogen supplies, reformate is still an option in terms of cost and reliability (Cheng et al., 2007).

In this context, PEMFC is relevant in the energy industry, and it is important to assess how it is implemented and how research and development (R\&D) in the area progressed. Thus, as part of the process for developing technological innovation, it is necessary to protect such technologies using Patent Rights. Patent is a temporary title on an invention, granted by the State to inventors, authors or other individuals or entities holding rights over the creation, which gives the holder the exclusive right of exploitation of a technology and thus the possibility of return on investments made in research and development (R\&D). In the other hand, the inventor must disclose in detail all the technical contents of the matter protected by patents, making the technology accessible to everyone. Moreover, they have to tell the public what barriers and technological "bottlenecks" they intend to overcome with that invention. Additionally, the technologies discussed in the patent application are cataloged by an international classification of technologies, known as the International Patent Classification (IPC).
Intellectual property in the form of patents is an important component of the commercial development of hightechnology industries like fuel cells thus providing a good indication of the competitiveness of different countries or companies. Therefore a patent analysis is necessary to study the Brazilian market and to determine the competitiveness of Brazil in some technical fields compared to other global competitors, in this study the field of fuel cells (Wietschel, 2004).

It is widely known that one new interesting technology will reflect in the growth of Research and Development activities and, therefore, will lead to an increase of patent applications. Therefore, it is known that new technologies can be identified by the analysis of patent applications in some fields. The results are generally presented quantitatively, but their use in the decision-making process is based on a qualitative evaluation (Carvalho et al., 2009).

Patent applications are among the most reliable and comprehensive sources of formal information when R\&D, technology and innovation are analyzed. Hence, patents can be considered indicators of R\&D in an industry and they are directly related to the process of technological innovation. Therefore, the information in these documents is essential for an overview of technological evaluation in a particular area (Carvalho et al., 2009). The Organization for Economic Co-operation and Development (OECD) uses patent information on a broad range of topics to help governments foster prosperity and fight poverty through economic growth and financial stability. OECD considers patent information an important indicator of technological development or R\&D.

However, the isolated existence of a patent system is not a sufficient condition for the economic development. An efficient patent system is an important tool for the scientific, technological and economic development of a country, however, other aspects must be taken into consideration and must be in sync like, for example, a national innovation system, a greater interaction between academia and business, the role of agencies, policies of tax incentives to small and medium enterprises, larger resources for investments in science and technology, the common view that technology is a competitive factor, and others (Muller, Antunes and Pereira Junior, 2006). 
For a better analysis of patent applications, techniques applied in technological forecasting studies, such as monitoring, are the most suitable, especially by the systematic use and the pre-established procedures worldwide, making research comparable with other studies in the area (Carvalho et al., 2009). Monitoring is the process in which pieces of information about foreseeing are monitored, identifying its sources, collecting, analyzing and structuring this information for its use. Thus, monitoring is crucial to any foresight (Coelho and Coelho, 2003).

The technological monitoring can be made by means of databases, like the Brazilian database of patents (INPIBR), Espacenet (ESPACENET) and Derwent World Patent Index (DWPI).

The Brazilian database of INPI is a database with 50,000 bibliographic records and abstracts of applications published in Brazil and weekly updated. The period covered is from 1982 on.

The database ESPACENET (ep.espacenet.com) is a database consisting of patent applications that are part of the search documents of the European Patent Office (EPO). It consists of a collection of more than 60 million patent applications from nearly every country in the world, with a period of coverage from 1836 on, and updated weekly. Through it, one has access to a collection of European papers, the PCT (Patent Cooperation Treaty), Japanese and other countries patents. Most documents can be completely retrieved. Furthermore, it provides the option to search by patent family. It also allows the access to the databases of industrial property offices of member countries. It is a database that contains bibliographic data, such as: number and publication date, filing date, number and unionist priority date, international patent classification (IPC), inventors' names, applicants' names and title.

The database Derwent World Patent Index (DWPI), available on the Portal.periodicos.Capes, is a patent database with more than 30 million patent documents filed in several countries. In addition, the titles and abstracts of patent applications of these databases are rewritten by experts in technological areas to facilitate the retrieval of patent applications through the keywords used in search strategies.
In this context, this paper intends to study the relevance of technologies on fuel cells that employ polymeric membrane and to show an overview of the Brazilian scenario in the development of PEMFCs technologies by technological monitoring study, through a survey of invention patent applications from Brazilian and foreigner applications filed at the National Institute of Industrial Property INPI from Jan-0I-1996 to Dec-3I-2005, featuring the innovations in the energy sector. This work also intends to analyze the uptrend of the use of this kind of fuel cell in the energy industry, the importance of its patenting, as well as the major applicant (s) and the country (ies) holding the technology, in order to anticipate the scientific and technological advances and influence the guidance of technological trajectories, guaranteeing competitiveness and the survival of industries and research institutions.

Moreover, the survey on the profile of applicants of patents related to PEMFC in Brazil, in this period, is aimed at depicting the panorama of marketing protection, offered by the patent system, as well as assist in the determination of the existing state of the art in terms of research and development.

\section{Method}

The methodology was based in technological monitoring technique and was implemented in five phases. The first one was the choice of the databases that would be used for retrieving the patent applications on technologies related to fuel cells. The selected databases were: I) the Brazilian database of patents (INPI-BR); 2) Espacenet (ESPACENET) and 3) Derwent World Patent Index (DWPI).

The searches were conducted on the databases ESPACENET and DWPI and were restricted to patent applications filed in Brazil (patent number $=\mathrm{BR}^{*}$ ), since the intention is to evaluate only the Brazilian market. All the searches were restricted until August 2008 and the databases (INPI-BR, ESPACENET and DWPI) were accessed in October 8, 2008.

The second phase was to prepare a search strategy for retrieving documents of interest. The International Patent Classification (IPC) to the technology of fuel cells, HOIM8 group ("Fuel Cells and their Manufacturing") was used in combination with keywords related to fuel cells ("fuel cell or battery cell") on the title and abstract fields. 
The third phase was to process and to organize the data into a table (first table), where the bibliographic data of the patent applications were entered: application number; unionist priority data (date, country and number), publication date; IPCs; abstract, title, name of applicant and name of the inventor.

The fourth phase was to read the titles and abstracts of tabulated documents, in order to eliminate those that could bring non-relevant information on the topic of fuel cells, due to the use of keywords in the search.

The period of the largest amount of patent applications related to Fuel Cells (from Jan-I-1996 to Dec-3I-2005) was analyzed on the fifth phase. Specifically, from this phase, data related to PEMFC technology were selected. Thus, another table (second table) was drawn, where the bibliographic data from these patent applications were inserted. The data from the second table were processed and statistics were done and determined trends in the patenting of PEMFC in Brazil.

\section{Results}

From all the retrieved patent applications until the fourth phase, 652 patent applications filed in Brazil were related to technologies on fuel cells. It was observed that the number of patents related to fuel cells began to grow sharply only in the 1990s. This result confirms the studies of Santos, Oliveira and Mendes (2009). This increase in the application number is, probably, due to the globalization process of the industrial world, which was already strong and had great influence on the strategies of research and development of companies, which have been forced to accelerate the development of new products.

Furthermore, in the fifth phase, it was observed that the largest concentration of deposits of patent applications happened in the period between 1996 and 2005. About 270 patent applications filed in Brazil, related to the topic of interest, were obtained and, thus, all the graphs and analyses regarding the patenting of technologies related to PEMFC were performed considering exactly 272 documents found in period between Jan-I-1996 and Dec-3I-2005.

Many patent applications found in the search were deposited via Patent Cooperation Treaty - PCT, which can impact the results, since the national deposits made via PCT may occur within the deadline of thirty months from the international filing date, or priority, if there is any. Thus, as the search was conducted until 2008, some patent applications may still enter the national phase in Brazil from 2006 until the survey date. In addition, the database Derwent only indexes the applications after the analysis of experts. This guarantees more reliable results until 2004 and ensures that all patent applications are already indexed and filed in Brazil.

From the results obtained in the second table, there were produced various graphs to analyze the Brazilian market: the main applicant country (Figure I), the profile of the applicants (Figure 2), the leading IPC (Figure 3), the expansion of the H0IM8 group (Figure 4), the expansion of the B0ID7I group (Figure 5), the number of patents on PEMFC filed in Brazil yearly (Figure 6) and the number of patent requests on PEMFC filed by Brazilians yearly (Figure 7).

Figure I shows the countries that stand out in the search for protection for their inventions in Brazil, indicating, thereby, the country of origin of the technology. The United States (U.S.) is the country which excels in this technology with $53.7 \%$ of patent applications, followed by Germany (DE) with $16.2 \%$. Brazil (BR), together with the United Kingdom (GB) occupy the fifth position as countries of origin of patent applications related to PEMFC technology filed in Brazil, each one accounting for olnly $4.4 \%$ of all applications found. Figure I indicates that Brazil and other Latin American countries have not had enough investments in this field and their number of applications is still very low. Nevertheless, these data could also indicate the huge growth potential of R\&D of cell fuels in these countries. 


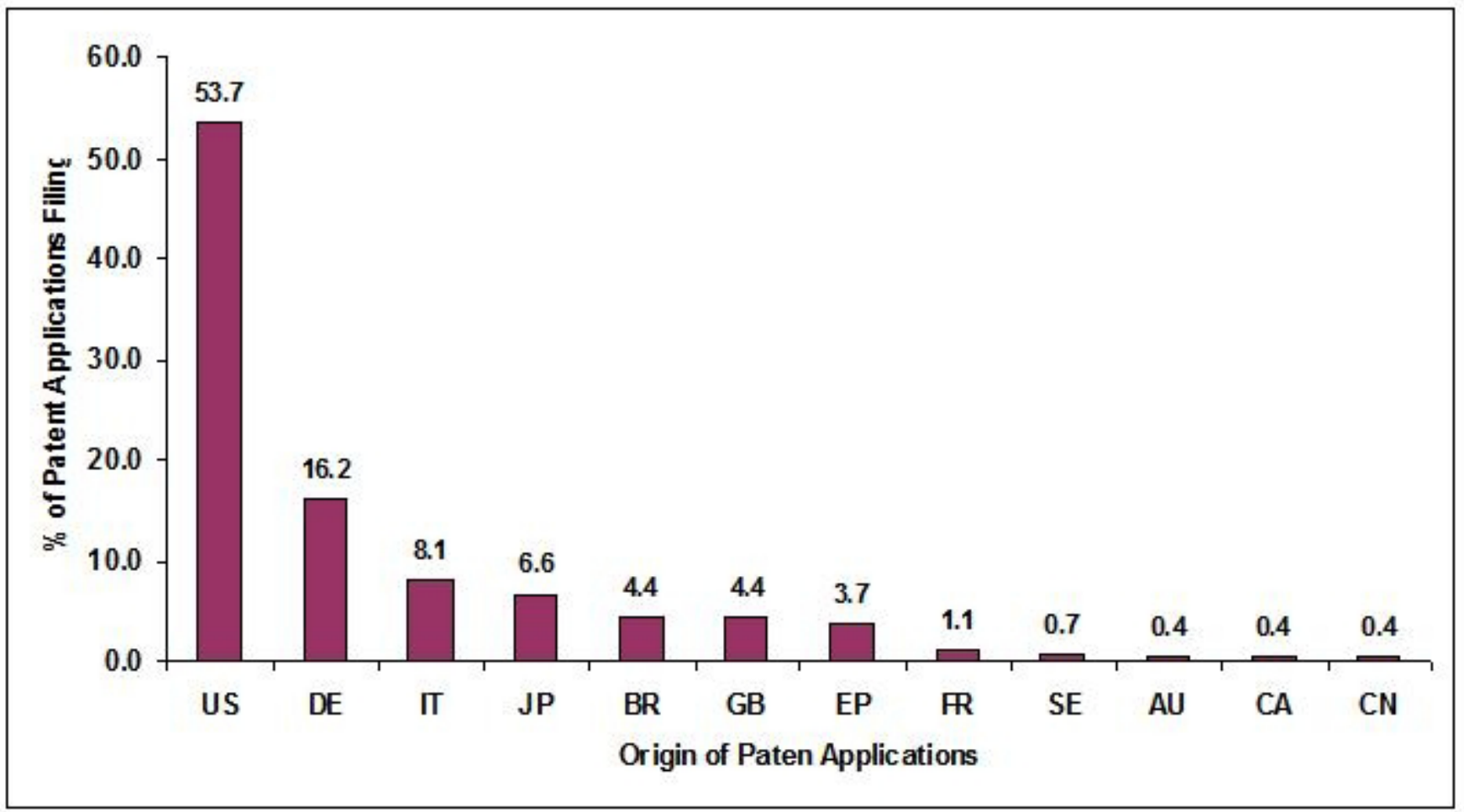

Figure I: Distribution of nationalities of applicants on technologies related to PEMFC filed in Brazil from 1996 to 2005.

Ninety-two different applicants of PEMFC patents were identified for the 272 documents found, and those who had at least three patent applications were considered to be the most important ones, that is, 28 different applicants were identified, as seen in Figure 2. It can be observed that most of the applicants are from the USA, followed by applicants from Germany. In Brazil, the applicant that stands out is the National Commission of Nuclear Energy, with 6 patent applications. 


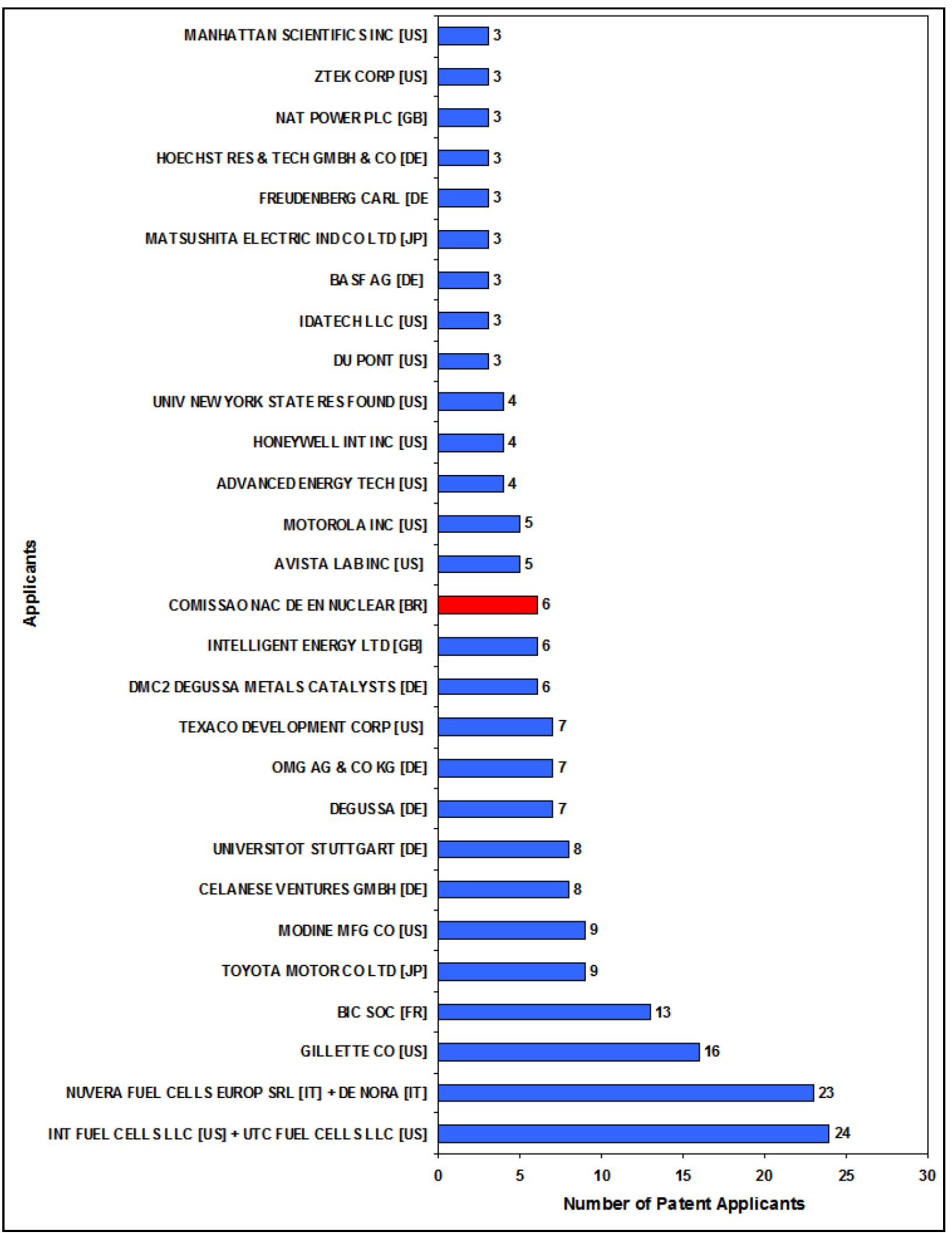

Figure 2: Main applicants on technologies related to PEMFC filed in Brazil from 1996 to 2005. 
UTC Fuel Cells Company comes on top of the list, holding 24 patent applications retrieved in the search. The North-American company UTC Fuel Cells, LLC merged with United Technologies Corp UTC Fuel Cells, LLC on January Ist, 2007, in order to develop and produce fuel cells to space, military, transportation, and commercial uses. The company was previously known as International Fuel Cells Corporation and changed its name to UTC Fuel Cells, LLC, in 200I. UTC Fuel Cells, LLC was founded in 1985. Currently, the company is developing PEMFC power plants that operate with propane and natural gas, to houses and light applications.

The second company in the rank, with 23 patent applications, was the Italian Nuvera Fuel Cells which was created in April 2000 after a merge between De Nora Fuel Cells (Italy) and Epyx Corporation (US). Nuvera Fuel Cells is now part of the De Nora Group. The De Nora fuel cells has been in the vanguard in the development of fuel cells in Italy for many years; working in the concept of buses and cars with international partners. Working on PEMFC, the company produces batteries and fuel processors to home and automotive applications. Nuvera Fuel Cells has also worked on PEMFC in order to power vehicles. Together with Fiat, the company presented two PEMFC cars in 2003.

The North-American company, The Gillette Company, is know for its work in personal hygiene, however, this company started to operate in this area after the acquisition of Duracell, which was a company of the energy sector. Thus, The Gillette Company also stands out, holding 16 patent applications.

In September 2004 the business units from Duracell, Gillette Company and MTI Micro Fuel Cells signed a deal to develop and commercialize complementary products of micro fuel cells. The deal establishes a partnership of exclusivity to the conception, development and commercialization of a methanol micro fuel cell and a compatible refueling system.

BIC is a company that also stands out in the PEMFC technology. The company is using its 30 years of experience in the technology of lighter valves in order to create fuel cell cartridges to electronic producers so they can be used in micro fuel cells. Nowadays, BIC has partnerships with many other companies (fuel cells and electronics producers included) and it's also working with associations and regulatory agencies all around the world as part of its efforts of investigation on the fuel cell cartridge business.

It should be mentioned that the number of patent applications from Brazilian applicants is very low compared to applicants that stood out. This probably happens in Brazil due to lack of information in the patent area. However, following a world tendency, the national industry has started to invest in the technology of fuel cells in 1998. It was initialized in the Institute of Energetic and Nuclear Research (IPEN) which is an autonomous organization managed by the National Commission of Nuclear Energy (CNEN). The initial studies, from 1998, were conducted in the area of materials, making use of the previous experience of the Institute on developing nuclear materials. In 2000, they established a research line in the area of efficient energy sources of low environmental impact, by means of the development of systems related to fuel cells technology.

Due to the success in the initial researches and the proposition of the Brazilian Program of Hydrogen Fuel Cells in 2002, currently named PROH2 from MCT, IPEN-CNEN/ SP, from July 2003 , it was encouraged to create, internally, an integrated hydrogen fuel cell development program. This program aims to manage R\&D and technological innovation on fuel cells in a way to contribute to the national development in the area. Thus, although the number of patent applications from Brazilian applicants is very low, it is possible to notice that the government is encouraging the development of the sector in the country.

It seems that the use of the IPC as a source of information is extremely necessary to evaluate this technological area, since it may have different applications for polymeric membranes in different areas and there are different kinds of fuel cells. Figure 3 shows the distribution of the International Patent Classification groups (IPC), present in the patent applications filed during the study period. In order to collect this data, up to 8 main classifications related to each patent application filed were computed, for one application may have other classifications. As it can be observed, the classification that was mostly found in the patent applications was H0IM8 (fuel cells; Manufacture thereof) with 583 entries. Such result was already expected, once this classification is specifically related to fuel cells and, besides that, the IPC group was used as a parameter in the search to retrieve the related documents. Moreover, this classification is the core of this study, which explains the big difference compared to other IPC found. 


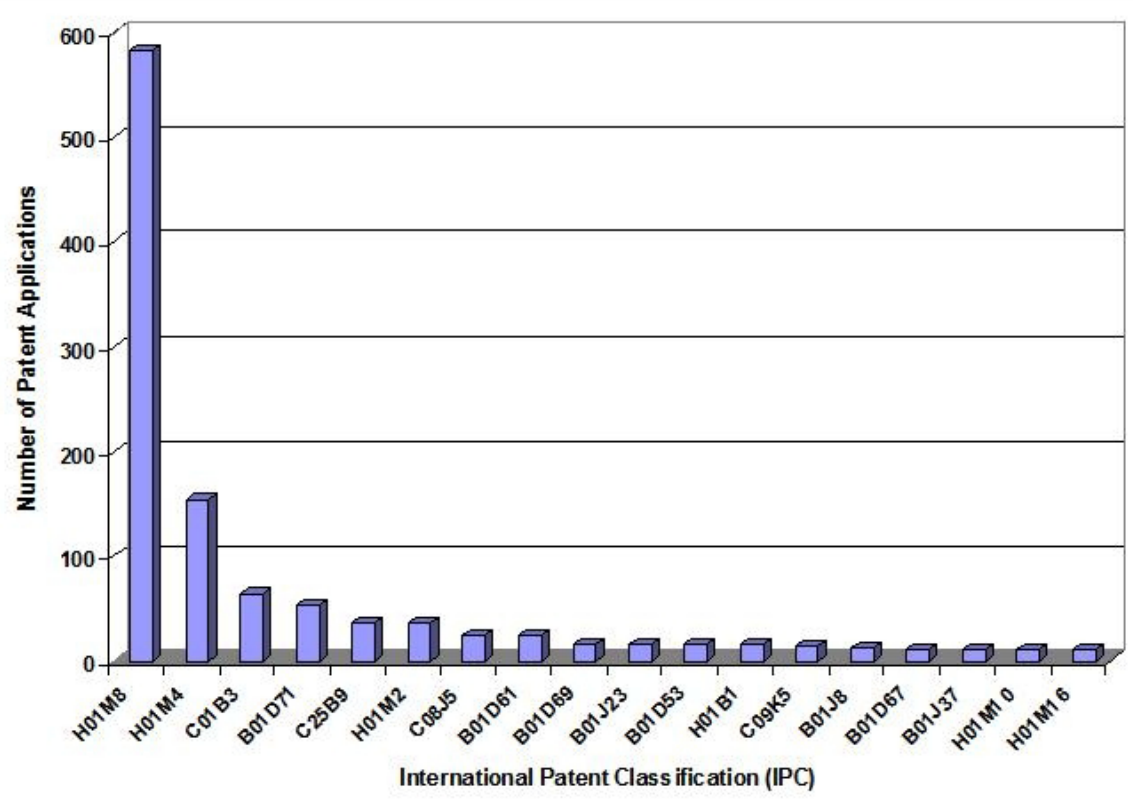

Figure 3: Distribution of IPCs with higher incidence of PEMFC patent applications filed in Brazil from 1996 to 2005.

The second classification with higher incidence is H0IM4 with 154 entries, which refers to fuel cells electrodes. The three other relevant classifications found are related to hydrogen (COIB3), to the semi-impervious membranes designed to processes or separation devices (B0ID7I) and to structural details or fabrication of non-active parts (H0IM2), among other classifications found.

Figure 4 shows the expansion of the H0IM8 group, which was mostly found. It was verified that the most expressive subgroup was the H0IM8/I0, with 152 entries, which is related to solid electrolyte fuel cells, like the PEMFC, in which its ionic exchange membrane is a solid polymer. This result shows the importance of this technology. The second subgroup that stands out is the H0IM8/04, followed by the subgroup H0IM8/02, which respectively refer to dispositions or auxiliary processes, i.e. to pressure control, to the circulation of fluids and details.

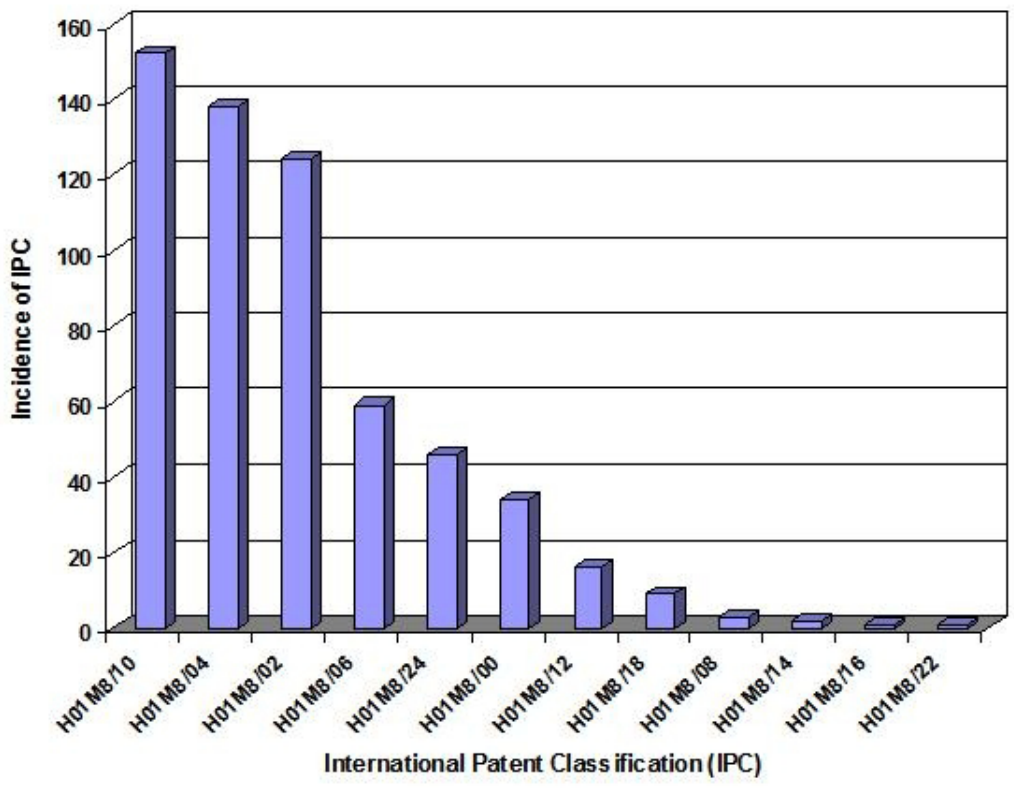

Figure 4: Expansion of the H0IM8 group from the IPCs with higher incidence in the patent applications of PEMFC filed in Brazil from 1996 to 2005. 
Aiming to verify specifically the membranes, the group B0ID7I was detailed (Figure 5). The analysis of this figure shows that the subgroup with higher incidence is the B0ID7I/02, with 10 entries, which is related to inorganic.
The subgroup B0ID7I/00, which is the second most frequent, ( 8 entries), is more general and encloses both, organic and inorganic membranes. The other subgroups are related to organic membranes, totaling 35 entries, differentiated only by the materials they are made of.

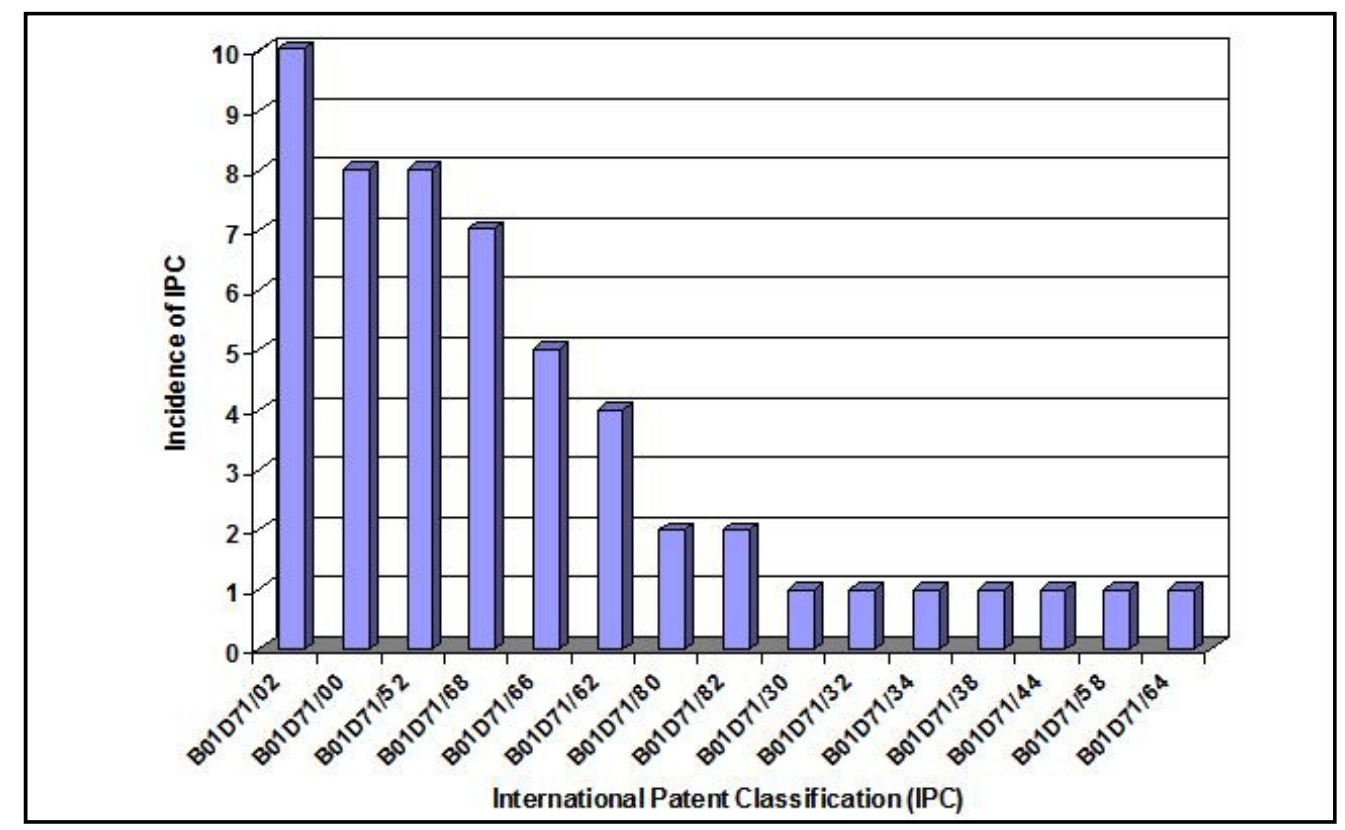

Figure 5: Expansion of the B0ID7I group from the IPCs with higher incidence in the patent applications of PEMFC filed in Brazil from 1996 to 2005.

This result confirms the studies of Ulbricht (2006), because it reveals that even though inorganic membranes have been known for a long time, in the last few years they started to compete in the market with polymeric membranes. However, organic membranes still dominate the market. This is probably due to the fact of the great variability of the properties and structures of block out. In addition, even though the inorganic membranes present a longer lifetime and are easier to clean, they are much more expensive than the polymeric membranes.

In order to monitor the technological innovation along time, it was decided that they would be verified according to how it developed by the priority date in the patent applications. Figure 6 reveals that the technologies related to fuel cells present a growing number of patent applications with priority between 1995 and 2005. It's worth mentioning that the year 2005 priorities refer to Brazilian patent applications with Brazilian priority, that is, the priority date coincides with the filing date. Also, like previously mentioned, one of the databases used was Derwent, that only indexes in its database the patent applications that have been analysed by experts, and, many patent applications retrieved in the search were filed via PCT, in a way that the most relevant and reliable results are the ones with priority date until 2004. 


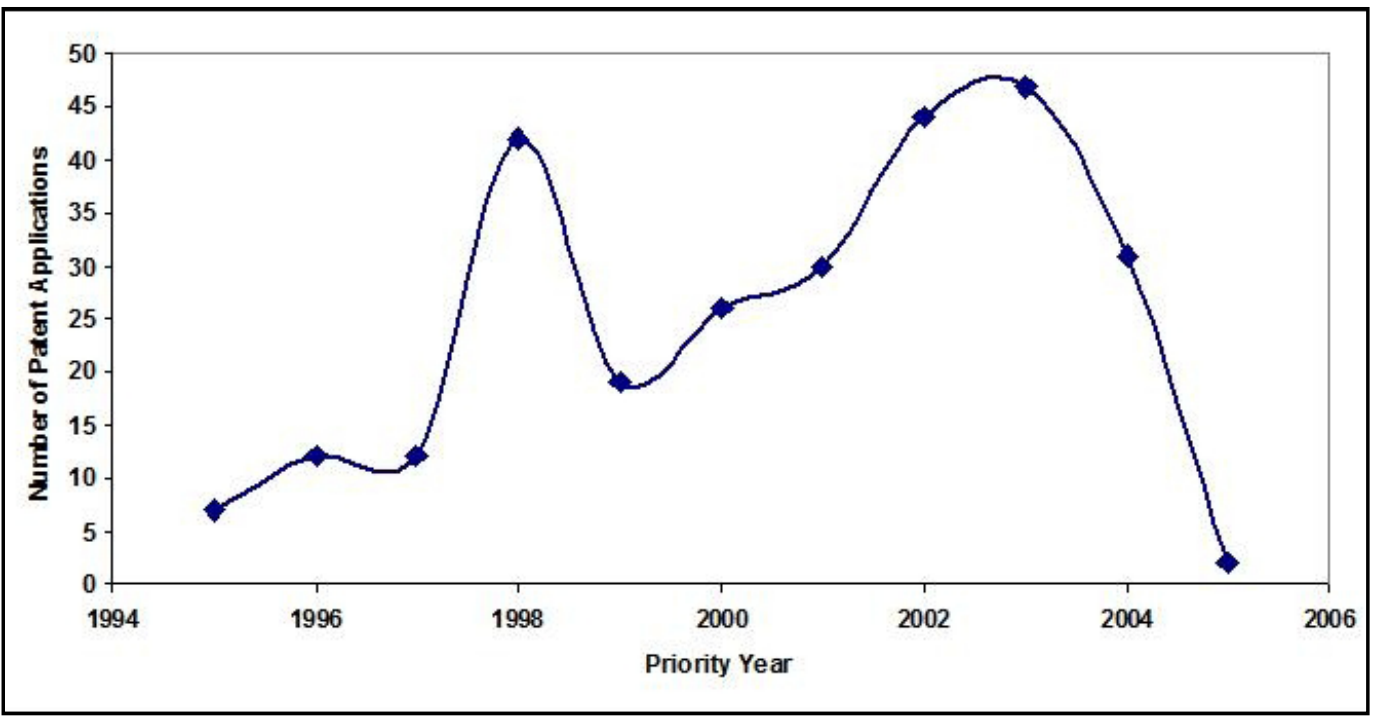

Figure 6: Number of patents of PEMFC filed in Brazil yearly, with a highlight to the priority date.

From 2000 to 2003 there was a peak in the number of applications called the "radical innovation" period. From this point on, there was a decrease in this kind of application that turned into "incremental innovations". This fact can be related with the increase of applications related to process improvements and/or composition. This observation is consistent with studies of Hemais et al. (2000), which implies that the maintenance of standards of competitiveness based on new products and processes are arising out of increasingly intense activities of research and development by companies.

Also, it can be observed that in 1998 there was a great increase in the number of applications with priority, probably due to the guidelines of the National Council for Energy Policy (CNPE). A large number of patent applications can also be observed in 2002, which may be due to the actions implemented by the government, related to the development in the energy sector, remarkably in the fuel cells area, like the creation of the Brazilian Program of Hydrogen and Fuel Cells System (PROCAC) by the Ministry of Science and Technology (MCT) in 2002 (called PROH2 since 2005) once the program aims to make viable the development of technologies on hydrogen and fuel cell systems nationally, in a way that Brazil becomes internationally competitive in this area.
Since many patent applications retrieved are from national applicants, it's also interesting to notice the political correlations in the area internationally. It's worth highlighting that in 1997 the Protocol of Kyoto was established, in Japan, and signed by 84 countries in 1998, where industrialized countries have committed to reduce its $\mathrm{CO} 2$ and other greenhouse effect gases emissions. Thus it's interesting to observe that, although the studies on fuel cells started some years ago, their development in this area (PEMFC) has been halted, probably due to the intense use of hydrocarbons as energy sources. However, in the last few years this reality has changed. With growing environmental problems and the pressures related to policies on environmental preservation, universities, companies and governments re-stared the researches in this area. This has contributed in a way that companies searched more and more for the development of clean technologies investing in environmental quality, which has made them more competitive. Thus, with the various investment policies on technology lately, it's likely that they have contributed to the great number of patents with priority these years. 
In this context, in 1996, the Department of Defense of the U.S. released their Climate Change Fuel Cell Program (Department of Defense's - DOD, Climate Change Fuel Cell Program). This program offers a $\$ 1.000$ dollars/kilowatt to buyers of fuel cell power plants. In 2000, the Department of Energy of the U.S. (DOE) reserved $\$ 135$ million dollars in financing to research including advanced fuel cell projects.

The DOE also approved $\$ 17.9$ million dollars in financial assistance, to finance new research on advanced fuel cells in three Massachusetts companies: Nuvera Fuel Cells, Mechanology LLC, and Arthur D. Little INC. In January 2002, the Secretary of Energy of the U.S.; Spencer Abraham, announced a new partnership in the automotive research called FreedomCAR, with the US Council for the Automotive Research (USCAR), and three major producers of automobiles: Ford, General Motors and DaimlerChrysler. This program aimed to step forward on the fuel cell automobiles and to face the problems related to infrastructure creation. Other countries, like Germany and Japan compete with the US in this area and are strongly promoting the development of fuel cells.
The German government increased its funds to research on non-nuclear technologies in 2000 , in order to equalize the funds from 1995, which had decreased by $30 \%$ until 1999. In 1998, Italy spent millions in the area. The PEM fuel cell program to 2000-2004 included the close cooperation among government and companies (fuel cells, automotive, and oil). Various options of fuels are considered, including traditional fuels like hydrogen and methanol. In Japan, the budget to fuel cells from the Ministry of International Trade and Industry (MITI), to year 2000 (FY2000), was nearly double the budget from 1999. Many Japanese companies are working on fuel cells, including Toyota, Toshiba, Suzuki and Sanyo.

Related to national applicants, with Brazilian priority (BR), it's observed that the profile of the curve (Figure 7) shows that the first patent application's priority is from 1998 and it was also filed in 1998 and that there was an increase in year 2000 , and the number of filed applications has kept steady.

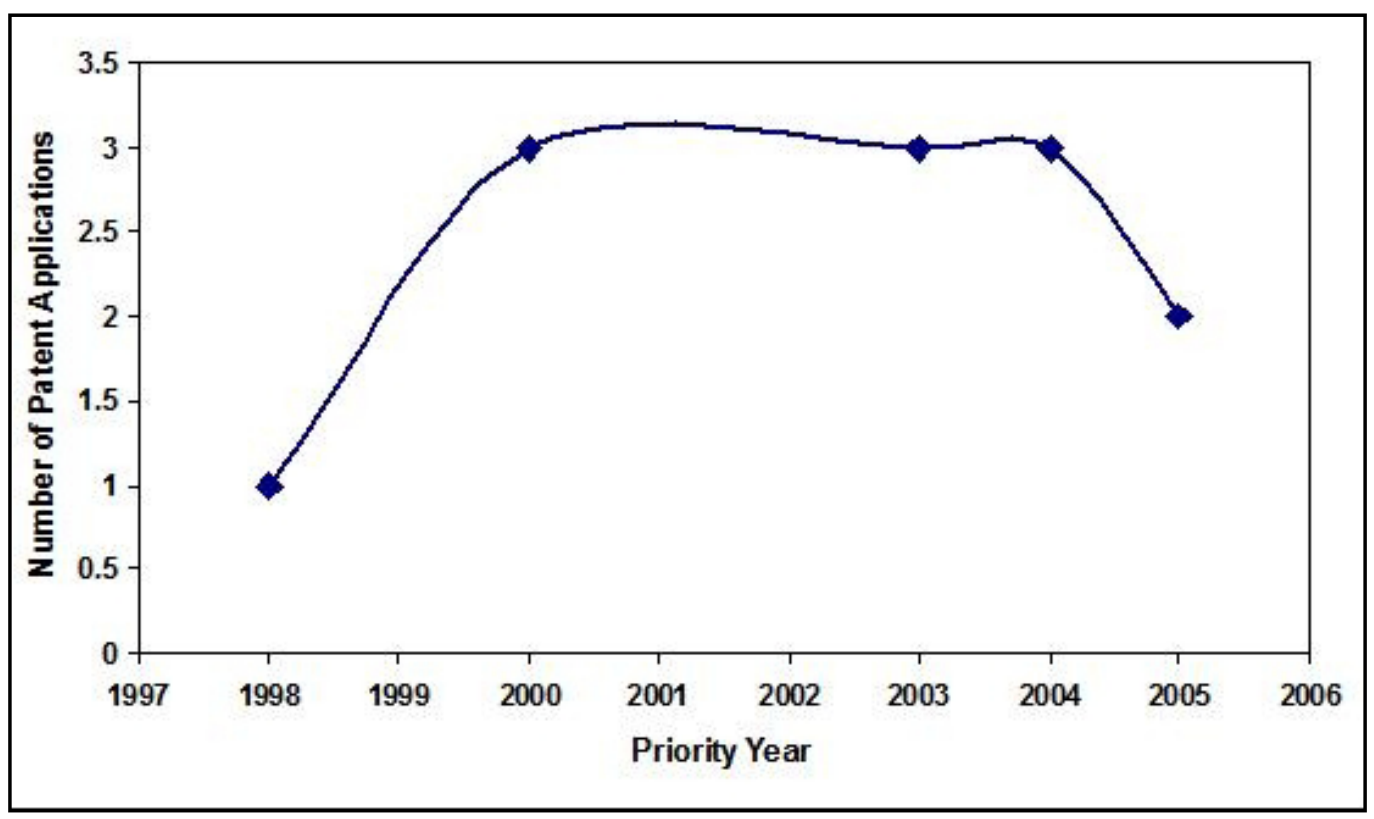

Figure 7: Number of patent requests of PEMFC filed in Brazil (Brazilian origin) yearly between 1996 and 2005, highlighting the priority date. 


\section{Discussion}

The present study showed the importance of patents as an instrument of technological innovation in the energy area and assessed the relevance of PEMFC technology in Brazil by means of the technological monitoring methodology, from 1996 to 2005. This monitoring consisted of a search on patent applications filed in Brazil, in three different databases, confirming that the number of patent applications filed can be used as an innovation indicator.

By the analysis of the collected data, it was observed that the number of patent applications filed by Brazilians is low compared to the total number, which demonstrated that the patent system in not well known as an instrument of protection of the nationally developed inventions. Furthermore, it was observed that there are no patent applications of Brazilian origin (BR) in other countries, which indicates the lack of an expansion plan of Brazilian activities in other countries, once one of the indicators of an expansion strategy of companies in other markets is the search for international patent protection, that is, they try to achieve protection by means of patent applications in various countries that offer a receptive market.

Moreover, it was possible to verify that the technology is not concentrated in only one company, but that many companies have sought for protection of its inventions by means of patent requests in Brazil. Although the NorthAmerican company, UTC Fuel Cells LLC, comes on top of the list with 24 patent requests, the second company that in terms of "protection-searching" was the Italian Nuvera Fuel Cells Europe from De Nora group, with 23 patent applications, that is, only I (one) less patent application than UTC Fuel Cells LLC. Also, it was possible to verify that the technology is not concentrated in only one country, because although many applicants are of American origin, several German companies are working in this market.

Although the use of this technology is restricted, due to the cost of the cell and the production and storage of hydrogen, it can be observed that the growth of this technology in the last few years probably happened because they are environmentally viable, once, even with the use of a fossil fuel, they do not produce harmful gases that contribute to the phenomenon of acid rains and do not release pollutant particles that put the air quality at risk, no hydrocarbon is spilled during the normal operation. Besides that, the advance of this technology also happe- ned, due to a world tendency and the growing need to movable and smaller sources of energy.

It can be concluded from this study that it is possible to verify the development of PEMFC technologies in Brazil by means of reliable databases of patent applications, which has demonstrated that the technology keeps growing, probably pushed by the worry about preserving the environment and the need for alternatives that are capable of lessening the global warming. This is true because the current energetic global situation demonstrates the dependency on electrical energy, making it clear that it's important to rationally use it and reduce pollutants and its production. Thus, this proves to be a promising technology and presents a variety of applications in daily life, like, in the automotive sector, auxiliary generation in electrical installations, generation of energy to portable equipment and spatial programs, being attractive if compared to other conventional technologies.

\section{References}

BASU, S. (2007). Recent Trends in Fuel Cell Science and Technology. Springer, New Delhi.

BIYIKOǦLU, A. (2005). Review of Proton Exchange Membrane Fuel Cell Models. International Journal of Hydrogen Energy, 30, $1181-1212$.

BRAGION, L. (2007). Economia do Hidrogênio no Brasil tem Pouco Investimento. ABVE.http://www.abve.org.br/ destaques/destaque77.shtml [Accessed April 10, 2010].

CARVALHO, D.S., Oliveira, L.G., Winter, E., Mothé, C.G. (2009). Technological Foresight Based on Citing ad Cited Patents of Cellulose with Pharmaceutical Applications. Journal of Technology Management \& Innovation, 4(4), 32 - 4I.

CHENG, X., Shi, Z., Glass, N., Zhang, L., Zhang, J., Song, D., Liu, Z., Wang, H., Shen, J. (2007). A Review of PEM Hydrogen Fuel Cell Contamination: Impacts, Mechanisms, and Mitigation. Journal of Power Sources, 165, 739 - 756.

COELHO, G.M., Coelho D.M.S. (2003). Prospecção Tecnológica: Metodologias e Experiências Nacionais e Internacionais - Nota Técnica 14. http://www.davi.ws/prospeccao tecnologica.pdf [Accessed April 17, 2010]. 
COSTA, D.A. (2007). Células Combustíveis: Uma Abordagem Contemporânea. Universidade Católica de Brasília. http://www.ucb.br/sites/100//18/TCC/2 $2007 / T C C$ DanielAlvesCosta.pdf [Accessed April 19, 2010].

FRANCHI, T.P. (2009). Utilização de Células a Combustível tipo PEM como Alternativa na Geração Auxiliar em Instalações Elétricas de Grande Porte. Universidade de São Paulo. http://www.teses.usp.br/teses/disponiveis/3/3/43/ tde-01072009-130017/pt-br.php [Accessed May 8, 2010]. HARTMUT, W., Götz, M., Linardi, M. (2000). Tecnologia de Células a Combustível. Química Nova, 23(4), 538-546.

HEMAIS, C.A., Rosa, E.O.R.; Barros, H.M. (1999). A não globalização tecnológica da indústria brasileira de polímeros medida por meio de patentes. Revista de Administração Contemporânea, 3(3), 157 - 176.

MULLER, A.C.A., Antunes, A.M.S., Pereira Junior, N. (2006). Gestão em Biotecnologia - O patenteamento em Biotecnologia (Cap. 2). E-papers, Rio de Janeiro.

SANTOS, S.S., Oliveira, L.G., Mendes, C.U.S. (2009). Pedidos de Patentes de Tecnologias Relativas a Células a Combustivel: Cenário Brasileiro. INPI. http://www.inpi. gov.br/menu-esquerdo/informacao/estudos html [Accessed September 19, 2009].

SOPIAN, K., Daud, W.R.W. (2006). Challenge and future developments in proton exchange membrane fuel cells. Renewable Energy, 31, 719- 727.

SRINIVASAN, S. (2006). Fuel Cells - From Fundamentals to Applications. Springer. New York, 44I - 553.

WIETSCHEL, M. (2004). Patents in fuel cells and hydrogen production. Fuel Cell Today. http://www.fuelcelltoday.com/media/pdf/archive/Article_846_Patents0804.pdf [Accessed May 15, 2010].

ULBRICHT, M. (2006). Advanced Functional Polymers Membranes. Polymer, 47, 2217 - 2262. 
J. Technol. Manag. Innov. 20II,Volume 6, Issue 2 